\title{
Determination of inosine 5'-monophosphate (IMP) and guanosine 5'-monophosphate (GMP) in yeast extracts using UV spectroscopy and chemometrics
}

\author{
Determinação de inosina 5'-monofosfato (IMP) e guanosina 5'-monofosfato (GMP) \\ em extratos de levedura utilizando espectroscopia UV e quimiometria
}

\author{
Regina Andreia Ferrari Pereira ${ }^{1,2}$, Cássia Ugucione ${ }^{2}$, Edenir Rodrigues Pereira-Filho ${ }^{1 *}$ (]) \\ 1 Universidade Federal de São Carlos (UFSCar), Departamento de Química, Grupo de Análise Instrumental Aplicada, São Carlos/SP - Brasil \\ 2 Departamento de Pesquisa e Desenvolvimento, Biorigin, Macatuba/SP - Brasil
}

\section{${ }^{*}$ Corresponding Author:}

Edenir Rodrigues Pereira-Filho, Universidade Federal de São Carlos (UFSCar), Departamento de Química, Grupo de Análise Instrumental Aplicada, Rodovia Washington Luis, km 235, Bairro Monjolinho, Caixa Postal: 676, CEP: 13565-905, São Carlos/SP - Brasil, e-mail: erpf@ufscar.br

Cite as: Determination of inosine 5'-monophosphate (IMP) and guanosine 5'-monophosphate (GMP) in yeast extracts using UV spectroscopy and chemometrics. Braz. J. Food Technol., v. 21, e2017127, 2018.

Received: Oct. 18, 2016; Accepted: Nov. 10, 2017

\section{Abstract}

This study proposed a method to determine the sum of the concentrations of inosine 5'-monophosphate (IMP) and guanosine 5'-monophosphate (GMP) in final and intermediate products through a combination of UV spectroscopy and multivariate calibration. Partial Least Squares regression (PLS regression) was used for the data analysis and the proposed methods presented errors of around $4 \mathrm{mg} / \mathrm{L}$. In addition, the analysis cost is 10 times lower than the reference chromatographic method and the analytical frequency is 20 samples/hour.

Keywords: Flavor enhancers; Spectrophotometric method; Chemometrics; Rapid analysis; Umami flavor.

\section{Resumo}

Neste estudo, foi proposto um método para determinar a somatória das concentrações de inosina 5'-monofosfato (IMP) e guanosina 5'-monofosfato (GMP) em produtos finais e intermediários, através de uma combinação de espectroscopia UV e calibração multivariada. Na proposição do método, empregou-se Partial Least Squares (PLS), para a análise de dados, e os métodos propostos apresentaram erros em torno de $4 \mathrm{mg} / \mathrm{L}$. Além disso, apresenta custo de análise 10 vezes menor quando comparado com o método cromatográfico de referência, sendo que a frequência analítica é de 20 amostras/hora.

Palavras-chave: Intensificadores de sabor; Método espectrofotométrico; Quimiometria; Análise rápida; Sabor umami.

\section{Introduction}

The development of easily applicable analytical methods with high analytical frequency for quality control and the identification of contaminants in mid-process and final food product components is a challenging task in the food industry. Several methods described in the literature include the use of an electronic tongue to evaluate the tastes of monosodium glutamate (MSG), disodium inosinate and guanylate umami (YANG et al., 2013), as well as the combination of multivariate calibration with spectro-analytical techniques for the simultaneous determination of herbicide levels (ZHANG; PAN, 2011).
Yeast extract is an ingredient widely used in the food industry as a nutritional supplement to reduce sodium in the final product and as a flavour enhancer. The naturally occurring proteins, amino acids, $B$ vitamins, micro and macro elements and ribonucleic acid (RNA) in yeast extract enhance the original flavour of the food. Several biotechnological processes can be used to produce yeast extract, and the nucleotides 5'IMP (inosine 5'-monophosphate) and 5'GMP (guanosine 5'-monophosphate) are responsible for the natural flavour intensification and enhancement of umami. The determination of the concentration of these components in the final product 
Determination of inosine 5'monophosphate (IMP) and guanosine 5'monophosphate (GMP) in yeast extracts using UV spectroscopy and chemometrics

Pereira, R. A. F. et al.

can be carried out by a combination of spectrophotometric and chemometric methods. This approach was presented by $\mathrm{Ni}$ et al. (2011) for the quantification of the following four flavour enhancers in commercial samples: maltol, ethyl maltol, vanillin and ethyl vanillin. Durán-Merás et al. (1993) proposed the use of derivate spectrophotometry for the determination of IMP and GMP in food samples. Acebal et al. (2008) also applied spectrophotometric methods in combination with chemometrics to determine IMP, GMP and MSG in commercial stock cube samples. The relative errors obtained for the prediction were from $2 \%$ to $3 \%$. The direct evaluation of raw materials in the food industry is a critical task in real time process quality control, in order to accelerate decision-making during production. To develop these methods, one must take into consideration the sample matrix complexity, analytical costs and robustness of the analytical method. The application of chemometric tools plays an important role in this scenario, establishing regression models for the prediction of both the characteristics and analyte concentrations. Bernardes and Barbeira (2016) used UV-Vis and spectrophotometric techniques to discriminate aged cachaças. Cantarelli et al. (2009) proposed a method to determine aspartame and acesulfame-K using molecular absorption spectrophotometry and the multivariate calibration mathematical approach. The results obtained were compared with a well-established high performance liquid chromatography (HPLC) method and the predicted error obtained was lower than $10 \%$

The goal of this study is to apply molecular spectrophotometric techniques (UV) and PLS regression (Partial Least Squares regression) (KUSWANDI et al., 2015) to determine the concentrations of IMP and GMP in mid-process products from a manufacturer of food flavour enhancers. The employment of chemometric tools, mainly PLS, in food analysis is a very interesting procedure in order to improve decision making in food quality control (MUNCK et al., 1998). The method proposed in this study was developed by collecting data from several yeast extract samples from mid-process products over an 18 month period.

\section{Material and methods}

In the proposed procedure, samples from a process production (named PP) were used and collected during several periods of the year. The samples were prepared by diluting the solid ( $80 \mathrm{mg}$ ) in deionized water, and subsequently filtered through a $0.22 \mu \mathrm{m}$ filter and transferred to a vial.

Reference concentrations of both analytes (IMP and GMP) were determined using a high performance liquid chromatographic (HPLC) method (Thermo Fisher, model 3000) with a C18 column (150 mm x $3.0 \mathrm{~mm}$; $3 \mu \mathrm{m}$, Sigma Aldrich) and ion pairing with hexylamine ( $5 \mathrm{mmol} / \mathrm{L})$ (COULIER et al., 2011). The injection volumes of the samples and standards were $10 \mu \mathrm{L}$, and the calibration curves for both analytes were from $0.5 \mathrm{mg} / \mathrm{L}$ to $23 \mathrm{mg} / \mathrm{L}$.

The ultraviolet (UV) spectra between $200 \mathrm{~nm}$ and $300 \mathrm{~nm}$ were recorded for each sample using a $\mathrm{HACH}$ (DR5000, USA) spectrophotometer. This equipment allows for data collection with good linearity up to absorbance values of 3.5 .

The spectral information and reference values were combined, and the Pirouette 4.2 software (Infometrix, Bothell, USA) was used to generate regression models to predict the sum of the IMP and GMP concentrations as determined using PLS regression. Table 1 shows the total number of samples collected, the IMP + GMP reference concentration range and the number of samples used to propose the calibration and the validation datasets. In this case, the data set was divided into equal parts for calibration and validation. The samples used in the validation dataset were not employed in the calibration process and were applied to evaluate the predictive capability of the proposed model.

\section{Results and discussion}

\subsection{Reference method performance}

As mentioned, a HPLC method was used to obtain reference values for both the GMP and IMP concentrations. The limits of detection (LOD) and of quantification (LOQ) for both analytes were $0.2 \mathrm{mg} / \mathrm{L}$ and $0.5 \mathrm{mg} / \mathrm{L}$, respectively. Reproducibility $(n=20)$ and repeatability $(n=6)$ were $6 \%$ and $1 \%$, respectively. One hundred and eighteen samples from the process production were collected and analysed during a period of more than one year. The reference values obtained using the HPLC method already described were used to propose the regression model.

Figure 1 shows the analytical signals obtained from the standards: IMP $20 \mu \mathrm{g} / \mathrm{L}, \mathrm{GMP} 20 \mu \mathrm{g} / \mathrm{L}$ and their mixtures $(20 \mu \mathrm{g} / \mathrm{L}$ of each). The IMP signals consisted of two peaks - one in the range from $200 \mathrm{~nm}$ to $225 \mathrm{~nm}$

Table 1. Sample characteristics and data set description for the proposed model.

\begin{tabular}{|c|c|c|c|c|c|}
\hline \multirow[b]{2}{*}{ Product } & \multirow{2}{*}{$\begin{array}{l}\text { Total number of } \\
\text { samples }\end{array}$} & \multicolumn{2}{|r|}{ Calibration set } & \multicolumn{2}{|r|}{ Validation set } \\
\hline & & Samples & $\begin{array}{c}\text { Concentration range } \\
(\mathrm{IMP}+\mathrm{GMP}), \mathrm{mg} / \mathrm{L}(\text { mean } \pm \mathrm{SD})\end{array}$ & Samples & $\begin{array}{c}\text { Concentration range } \\
(\mathrm{IMP}+\mathrm{GMP}), \mathrm{mg} / \mathrm{L}(\text { mean } \pm \mathrm{SD})\end{array}$ \\
\hline $\begin{array}{c}\text { Product } \\
\text { Process (PP) }\end{array}$ & 118 & 59 & $\begin{array}{c}8.9-35.0 \\
(24.5 \pm 4.9)\end{array}$ & 59 & $\begin{array}{l}13.0-37.0 \\
(24.8 \pm 4.8)\end{array}$ \\
\hline
\end{tabular}


Determination of inosine 5'monophosphate (IMP) and guanosine 5'monophosphate (GMP) in yeast extracts using UV spectroscopy and chemometrics

Pereira, R. A. F. et al.

and the other at $250 \mathrm{~nm}$. GMP presented a shoulder from $275 \mathrm{~nm}$ to $280 \mathrm{~nm}$. After $300 \mathrm{~nm}$ no chemical information was observed and the absorbance was at the baseline. Thus further calculations were only considered in the region from $200 \mathrm{~nm}$ to $300 \mathrm{~nm}$.

Figure 2a shows the analytical signals for the product obtained from the process. As shown in the figure, there are baseline issues and a small shoulder at $275 \mathrm{~nm}$ to $280 \mathrm{~nm}$. In this case, normalization using the norm and the first derivative (with a window of 19 points) were applied to correct signal fluctuation and baseline problems, respectively (Figure 2b). The dataset was subsequently mean-centred as shown in Figure 2c. The UV-Vis equipment used allows one to obtain absorbance values with good linearity up to 3.5. Despite this, some saturation was observed in a few samples. Since the proposed chemometric method is intended to be a fast quality control method, none of the samples were eliminated from the model.

The data were then equally divided into two sets (calibration and validation; see Table 1), and a multivariate model was calculated for the product obtained from the process.

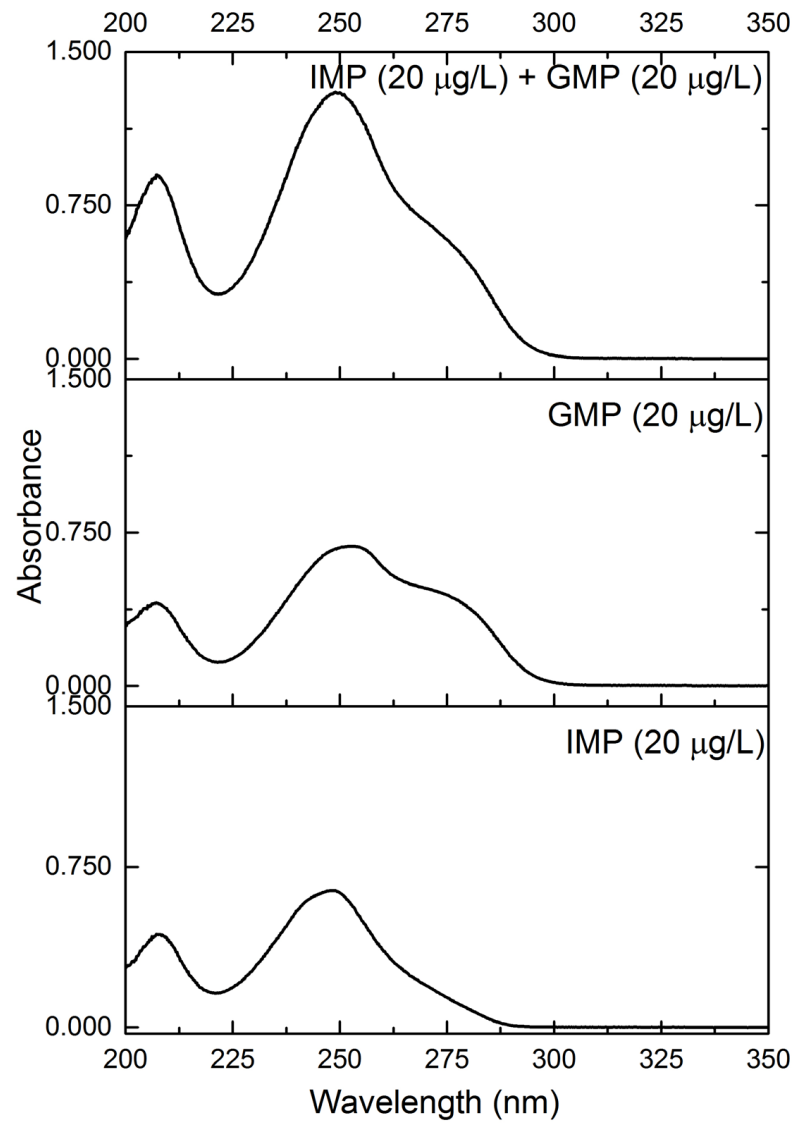

Figure 1. Spectra (200 nm to $350 \mathrm{~nm}$ ) obtained for the individual standards of IMP $(20 \mu \mathrm{g} / \mathrm{L})$ and GMP $(20 \mu \mathrm{g} / \mathrm{L})$ and their mixture.
One of the most important parameters in the configuration of the PLS regression model is the selection of the proper number of latent variables (LVs). In the case of the product obtained from the process, 3 LVs were necessary, and Figure 3 shows the number of latent variables versus the standard error of cross validation (SECV, leave-one-out). The SECV value was lower than $3.5 \mathrm{mg} / \mathrm{L}$. In order to verify
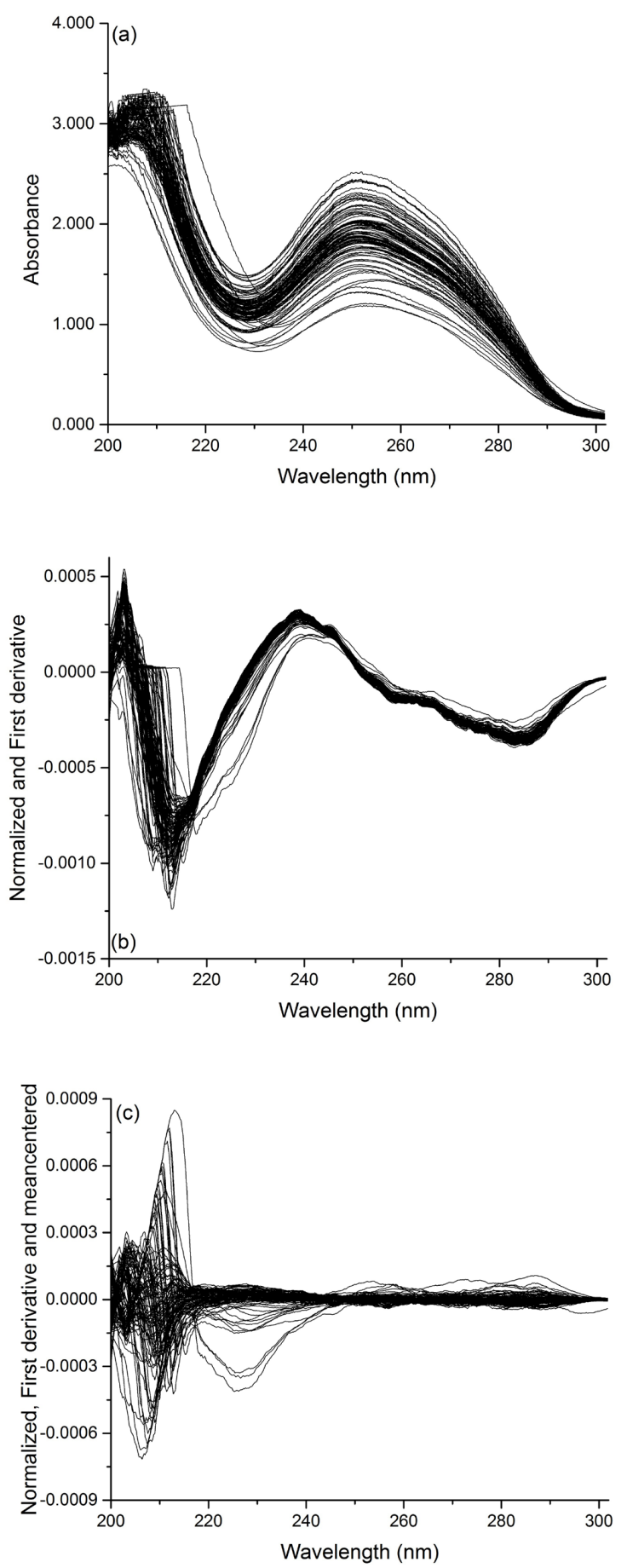

Figure 2. Spectra (200 nm to $300 \mathrm{~nm}$ ) for the product obtained from the process (a), data after normalization using the norm and first derivative (b) and mean-centred (c). 
Determination of inosine 5'monophosphate (IMP) and guanosine 5'monophosphate (GMP) in yeast extracts using UV spectroscopy and chemometrics

Pereira, R. A. F. et al.

if the model was obtained by chance, 29 PLS models were calculated changing the number of samples in the leave out process (from 1 to 29). In all models, the calculated SECV values ranged from 3.3 (29 samples leave out and $2 \mathrm{LVs}$ ) to 3.8 (22 samples leave out and 2 LVs). For the 29 models calculated, 7, 21 and 1 required 2, 3 and 4 LVs. Different numbers of LVs were selected in order to obtain a cumulative explained variance higher than $60 \%$. As can be observed, the models were very homogeneous and the error values varied within a small range.

As indicated in Figures 1 and 2, the most important regression vectors were between $200 \mathrm{~nm}$ and $300 \mathrm{~nm}$. Figure 4 shows the regression vector for the PLS model proposed. As can be observed, the wavelengths from $200 \mathrm{~nm}$ and $300 \mathrm{~nm}$ presented high values, in agreement with Figure 1 (pure IMP and GMP standards).

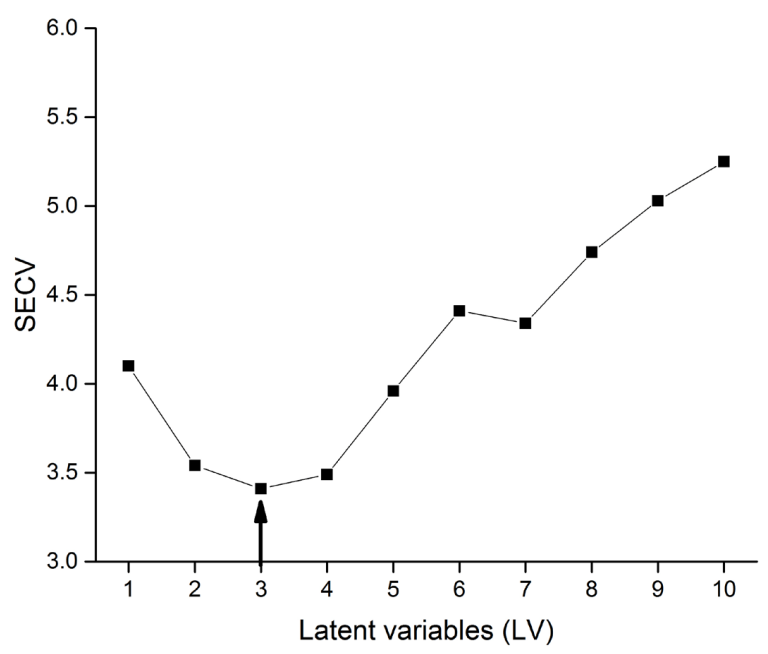

Figure 3. Latent variables (LV) versus standard error of cross validation (SECV, $\mathrm{mg} / \mathrm{L}$ ) for the regression model proposed for the product obtained from the process.

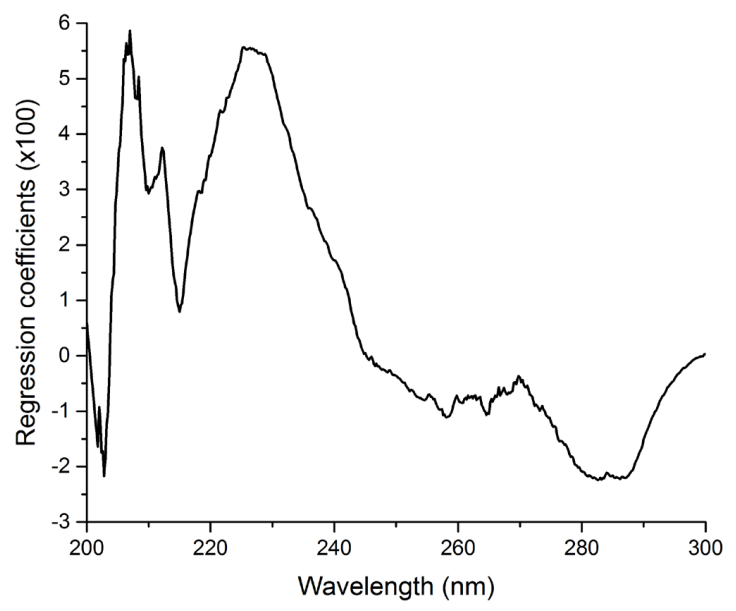

Figure 4. Regression vectors for the calculated PLS model.
The value for SEC (standard error of calibration) was also determined for the PLS regression model. Table 2 shows the PLS parameters obtained as well as the SEV (standard error of validation), and the errors were low. In addition, the value for SEV was higher than the values for SEC and SECV, and the model showed no overfitting.

In the chromatographic method (reference method), the relative errors comparing the mean reference value and its replicates $(n=3)$ ranged from $0.1 \%$ to $4.1 \%$. For the proposed UV spectroscopy combined with PLS regression model, the relative errors comparing the reference and the predicted values ranged from $-74 \%$ to $41 \%$ (average $-2 \%$ ). Figure 5 shows the reference versus the predicted concentrations for PP. This figure also shows the $\mathrm{R}^{2}$ values and the linear equations for both the calibration and validation data sets.

Figure 6 shows the range distribution for the relative errors and the accuracy of the calculated model.

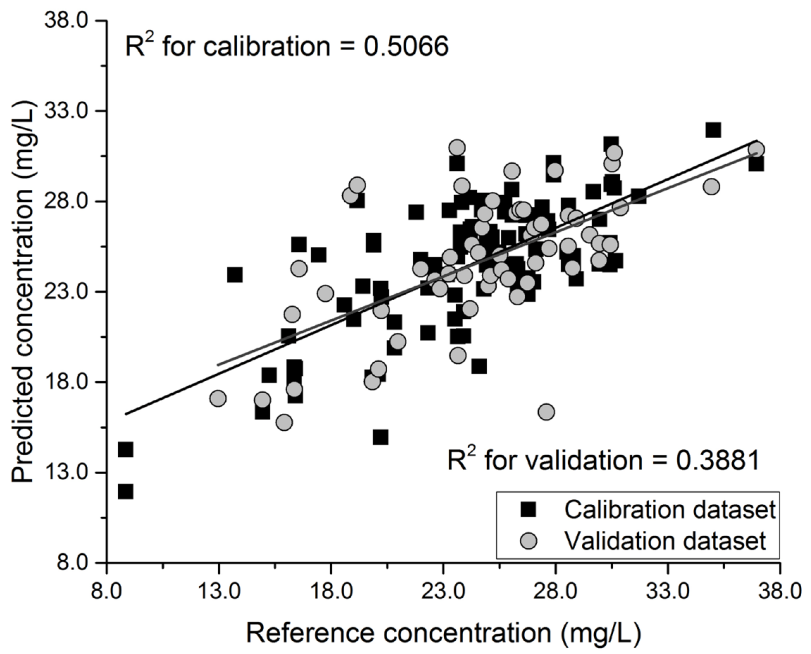

Figure 5. Reference versus predicted concentrations (IMP + GMP mg/L) for $\mathrm{PP}$, considering the calibration (squares, $\mathrm{R}^{2}$ of 0.5066 ) and validation (circles, $R^{2}$ of 0.3881 ) datasets. The figure also presents the fitted lines for the calibration and validation datasets.
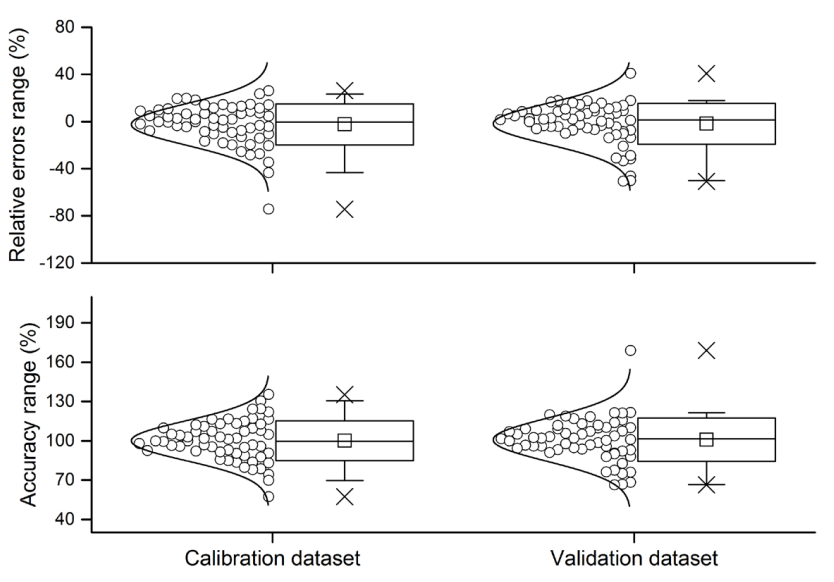

Figure 6. Relative errors (\%) and accuracy (\%) for the calibration and validation datasets for the calculated model. 
Determination of inosine 5'monophosphate (IMP) and guanosine 5'monophosphate (GMP) in yeast extracts using UV spectroscopy and chemometrics

Pereira, R. A. F. et al.

Table 2. PLS regression models proposed for the three products evaluated.

\begin{tabular}{|c|c|c|c|c|c|}
\hline \multirow[t]{2}{*}{ Model/product } & \multicolumn{4}{|c|}{ Calibration set } & \multirow{2}{*}{$\frac{\text { Validation set }}{\text { SEV }^{2}}$} \\
\hline & L.V. a $^{a}$ & $\%^{b}$ & SECV & SEC $^{d}$ & \\
\hline Product obtained from the process (PP) & 3 & 80 & 3.4 & 3.2 & 3.8 \\
\hline
\end{tabular}

aLatent variable; ${ }^{b}$ Explained variance; ' Standard error of cross-validation (mg/L); ${ }^{d} S E$ for calibration (mg/L); eSE for validation (mg/L).

The accuracy was calculated comparing the reference value (chromatographic method) with the predicted value. The results obtained for the product obtained from the process were satisfactory and can be used for fast determinations of analytes.

As shown in Figure 5, the proposed method was able to satisfactorily predict the sum of the IMP and GMP in the product obtained from the process. This method was also 10-fold less expensive as compared to the chromatographic one. In addition, fewer chemical by-products were generated, and the analytical frequency was approximately 20 samples per hour.

All papers related to the determination of IMP and GMP in foods employed the UV-Vis region (ACEBAL et al., $2008,2010)$ and no research was encountered using near or mid infrared (NIR and MIR).

\section{Conclusions}

This study shows the combination of UV spectrophotometric measurements with regression models to determine the sum of IMP and GMP in mid-process products. The method is robust and generates fewer chemical by-products as compared to the chromatographic reference method. This alternative model is a promising approach to accelerate the decision-making process for a flavour enhancement manufacturer. In addition, suspicious values with high relative errors can be further confirmed using the chromatographic method.

\section{Acknowledgements}

The authors are grateful to the Post-graduation programme in Chemistry (Programa de pós graduação em Química - PPGQ) at Universidade Federal de São Carlos - UFSCar (São Carlos, SP, Brazil) for the opportunity to develop this study during the professional master's course, and to the National Council for Scientific and Technological Development (Conselho Nacional de Desenvolvimento Científico e Tecnológico - 305637/2015-0).

\section{References}

ACEBAL, C. C.; GRÜNHUT, M.; LISTA, A. G.; FERNÁNDEZ BAND, B. S. Successive projections algorithm applied to spectral data for the simultaneous determination of flavour enhancers. Talanta, v. 82, n. 1, p. 222-226, 2010. http://dx.doi.org/10.1016/j. talanta.2010.04.024. PMid:20685460.
ACEBAL, C. C.; LISTA, A. G.; FERNÁNDEZ BAND, B. S. Simultaneous determination of flavor enhancers in stock cube samples by using spectrophotometric data and multivariate calibration. Food Chemistry, v. 106, n. 2, p. 811-815, 2008. http://dx.doi.org/10.1016/j.foodchem.2007.06.009.

BERNARDES, C. D.; BARBEIRA, P. J. S. Different chemometric methods for the discrimination of commercial aged cachaças. Food Analytical Methods, v. 9, n. 4, p. 1053-1059, 2016. http:// dx.doi.org/10.1007/s12161-015-0284-6.

CANTARELLI, M. A.; PELLERANO, R. G.; MARCHEVSKY, E. J.; CAMIÑA, J. M. Simultaneous determination of aspartame and acesulfame-K by molecular absorption spectrophotometry using multivariate calibration and validation by high performance liquid chromatography. Food Chemistry, v. 115, n. 3, p. 1128-1132, 2009. http://dx.doi.org/10.1016/j.foodchem.2008.12.101.

COULIER, L.; BAS, R.; HEKMAN, M.; VAN DER WERFF, B. J. C.; BURGERING, M.; THISSEN, U. Comprehensive analysis of Umami compounds by ion-pair liquid chromatography coupled to mass spectrometry. Journal of Food Science, v. 76, n. 7, p. C1081C1087, 2011. http://dx.doi.org/10.1111/j.1750-3841.2011.02306.x. PMid:21824139.

DURÁN-MERÁS, I.; DE LA PEÑA, A. M.; ESPINOSA-MANSILLA, A.; SALINAS, F. Multicomponent determination of flavour enhancers in food preparations by partial least squares and principal component regression modelling of spectrophotometric data. Analyst, v. 118, n. 7, p. 807-813, 1993. http://dx.doi.org/10.1039/ AN9931800807. PMid:8372976.

KUSWANDI, B.; CENDEKIAWAN, K. A.; KRISTININGRUM, N.; AHMAD, M. Pork adulteration in commercial meatballs determined by chemometric analysis of NIR spectra. Food Measurement, v. 9, n. 3, p. 313-323, 2015. http://dx.doi.org/10.1007/s11694015-9238-3.

MUNCK, L.; NORGAARD, L.; ENGELSEN, S. B.; BRO, R.; ANDERSSON, C. A. Chemometrics in food science: a demonstration of the feasibility of a highly exploratory, inductive evaluation strategy of fundamental scientific significance. Chemometrics and Intelligent Laboratory Systems, v. 44, n. 1-2, p. 31-60, 1998. http://dx.doi.org/10.1016/S0169-7439(98)00074-4.

NI, Y.; CHEN, J.; KOKOT, S. Simultaneous spectrophotometric kinetic determination of four flavor enhancers in foods with the aid of chemometrics. Journal of AOAC International, v. 94, n. 4, p. 1210-1216, 2011. PMid:21919354. 
Determination of inosine 5'monophosphate (IMP) and guanosine 5'monophosphate (GMP) in yeast extracts using UV spectroscopy and chemometrics

Pereira, R. A. F. et al.

YANG, Y.; CHEN, Q.; SHEN, C.; ZHANG, S.; GAN, Z.; HU, R.; ZHAO, J.; NI, Y. Evaluation of monosodium glutamate, disodium inosinate and guanylate umami taste by an electronic tongue. Journal of Food Engineering, v. 116, n. 3, p. 627-632, 2013. http://dx.doi.org/10.1016/j.jfoodeng.2012.12.042.
ZHANG, G.; PAN, J. Simultaneous spectrophotometric determination of atrazine and cyanazine by chemometric methods. Spectrochimica Acta. Part A, Molecular and Biomolecular Spectroscopy, v. 78, n. 1, p. 238-242, 2011. http://dx.doi. org/10.1016/j.saa.2010.09.028. PMid:20974548. 